\title{
Molecular Mechanisms for Coping with Al Toxicity in Plants
}

\author{
Xiang Zhang, Yan Long, Jingjing Huang and Jixing Xia *D
}

State Key Laboratory for Conservation and Utilization of Subtropical Agro-bioresources, College of Life Science and Technology, Guangxi University, Nanning 530004, China; 1708304025@st.gxu.edu.cn (X.Z.); 1808301038@st.gxu.edu.cn (Y.L.); 1808301015@st.gxu.edu.cn (J.H.)

* Correspondence: xiajx@gxu.edu.cn; Tel.: +86-0771-3236616

Received: 6 March 2019; Accepted: 25 March 2019; Published: 28 March 2019

\begin{abstract}
Aluminum (Al) toxicity is one of the major constraints to agricultural production in acid soils. Molecular mechanisms of coping with $\mathrm{Al}$ toxicity have now been investigated in a range of plant species. Two main mechanisms of $\mathrm{Al}$ tolerance in plants are $\mathrm{Al}$ exclusion from the roots and the ability to tolerate $\mathrm{Al}$ in the roots. This review focuses on the recent discovery of novel genes and mechanisms that confer $\mathrm{Al}$ tolerance in plants and summarizes our understanding of the physiological, genetic, and molecular basis for plant $\mathrm{Al}$ tolerance. We hope this review will provide a theoretical basis for the genetic improvement of $\mathrm{Al}$ tolerance in plants.
\end{abstract}

Keywords: aluminum; $\mathrm{Al}$ toxicity; $\mathrm{Al}$ exclusion; $\mathrm{Al}$ tolerance; $\mathrm{Al}$ transporter

\section{Introduction}

Aluminum (Al) is the third most abundant element in the earth crust, after Oxygen and Silicon, and the most plentiful metallic element in soil. Al is considered non-toxic to plants when located in near-neutral or alkalescent soil. However, natural processes or human activities can lead to soil acidification $(\mathrm{pH}<5.5)$, the production of $\mathrm{Al}$ ions (mainly $\mathrm{Al}^{3+}$ ) from $\mathrm{Al}$ oxides, and phytotoxicity. Over $30 \%$ of the land and over $40 \%$ of the potential arable land are acidic [1], most of which is distributed in the tropics and subtropics, in which important commercial and food crops are planted. Al toxicity limits crop yields by inhibiting root growth and influencing the absorption of water and nutrients [1]. A number of studies have described $\mathrm{Al}$ targets in root cells with perturbations to the cell wall, plasma membrane, mitochondria, cytoskeleton, and nucleus [2-6]. Thus, it influences an array of cellular processes including reactive oxygen species (ROS) generation, signal transduction disorder, and lower cell wall extensibility, thereby impairing plant growth [2-12].

To deal with $\mathrm{Al}$ toxicity, plants possess several strategies to reduce the noxious consequences of $\mathrm{Al}$ toxicity during the evolutionary process. These mechanisms can be divided into (i) Al exclusion mechanisms that prevent $\mathrm{Al}$ entering root cells (both apoplastic and symplastic pathway) by secreting organic acid (citrate, malate, and oxalate) to chelate $\mathrm{Al}$ cations and (ii) $\mathrm{Al}$ tolerance mechanisms in which $\mathrm{Al}$ enters root cells and is detoxified and sequestered into vacuoles or other organelles in roots and /or shoots (Figure 1) [5,6,13,14]. 


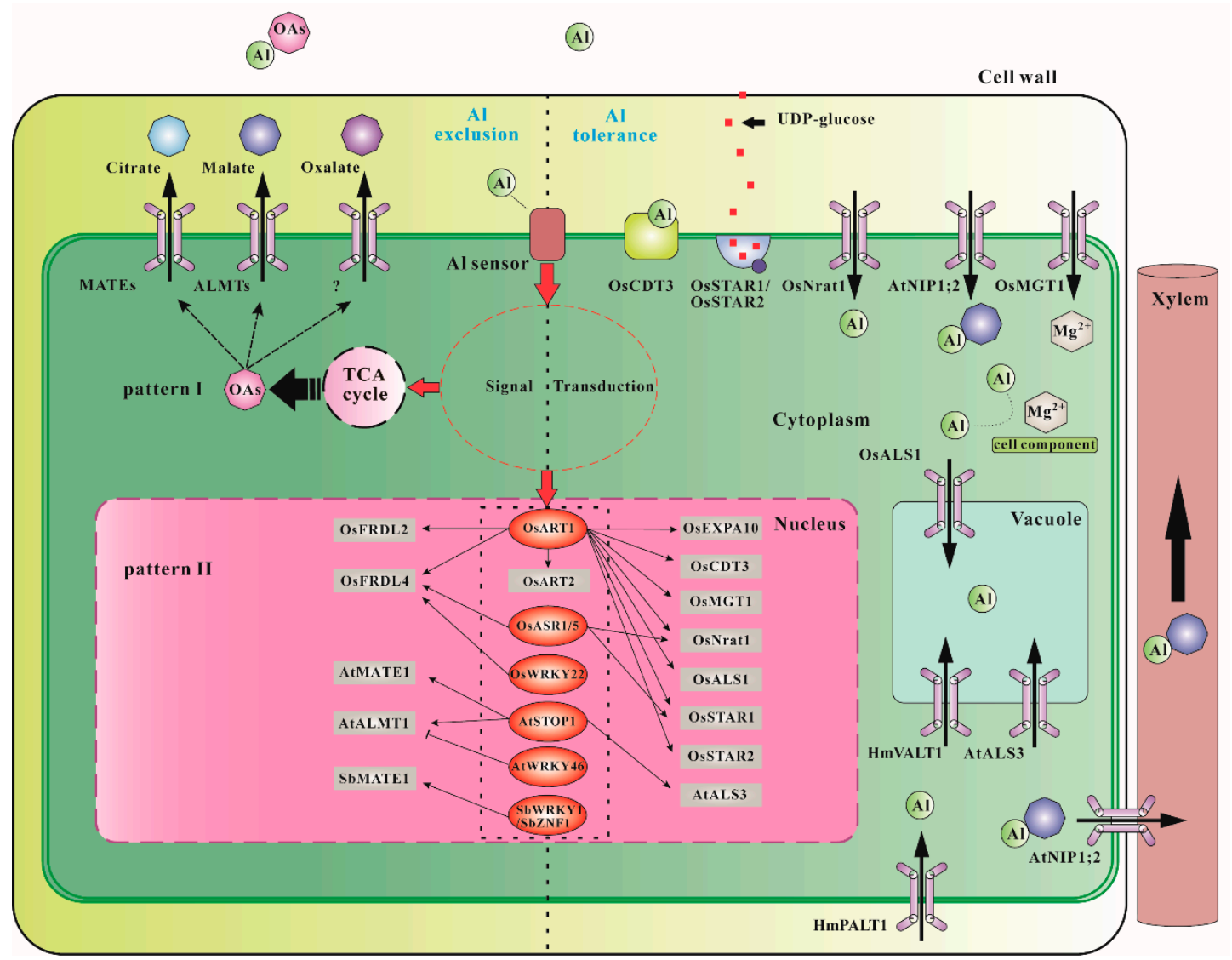

Figure 1. Mechanisms of Al tolerance in plants. MATEs, multidrug and toxic compound extrusion for citrate transport; ALMTs, aluminum-activated malate transporters; OsCDT3, a small peptide with rich cysteine; OsSTAR1/OsSTAR2, UDP-glucose transporter; OsEXPA10, an expansin gene; OsNrat1, plasma membrane-localized Al transporter; AtNIP1;2, plasma membrane-localized Al-malate transporter; AtALS3, plasma membrane-localized Al transporter; HmPALT1, plasma membrane-localized Al transporter; OsMGT1, magnesium transporter; OsALS1, tonoplast-localized Al transporter; HmVALT1, tonoplast-localized Al transporter; OsFRDL2/4, citrate transporter; AtMATE1, citrate transporter; AtALMT1, malate transporter; OsASR1/5, ABA-stress and ripening 1/5; OsART1/2, $\mathrm{C}_{2} \mathrm{H}_{2}$-type zinc finger transcription factor; AtSTOP1, C2H2-type zinc finger transcription factor; OsWRKY22, WRKY transcription factor; AtWRKY46, WRKY transcription factor; SbWRKY1, WRKY transcription factor; SbZNF1, DHHC-type zinc finger transcription factor; SbMATE1, citrate transporter.

Several reviews have described the research progress made on molecular mechanism of $\mathrm{Al}$ tolerance in gramineous plants or crops several years ago [12-14]. In recent years, a number of new Al-tolerant genes have been identified by using different approaches in higher plants. In the present review, we provide brief summaries on recent discoveries of new genes and molecular mechanisms by which plants cope with $\mathrm{Al}$ toxicity. In addition, we provide a perspective on future researches and challenges of the molecular mechanism of $\mathrm{Al}$ tolerance and its application for enhancing crop $\mathrm{Al}$ tolerance and improving crop yields on acid soils.

\section{Al Exclusion Mechanisms}

It is well-known that root apex is the critical region of Al toxicity. Many plants secrete organic acid (malate, citrate, and oxalate) from the root tip in response to $\mathrm{Al}$ stress, which prevents trivalent $\mathrm{Al}$ ion from entering root tip cells. Two transporter families that confer $\mathrm{Al}$ tolerance through the secretion of organic acids have been identified in plants (Table 1). These include ALMT (aluminum-activated malate transporter) and MATE (Multidrug and toxic compound extrusion). The first identified malate efflux gene was TaALMT1 from wheat [15]. This protein is a membrane-localized transporter that 
participates in the efflux of malate from roots in response to Al stress. Homologs of TaALMT1 have been found in other species such as Arabidopsis, rape, maize, soybean, rye, Medicago sativa, Holcus lanatus, and rice [16-26]. Among these homologs, AtALMT1, BnALMT1/2, ScALMT1, GmALMT1, ScALMT1, MsALMT1, and HIALMT1 share similar functions to TaALMT1, which is involved in Al tolerance by mediating the secretion of organic acids. Other identified homologs are found to be unrelated to Al tolerance and involved in other functions. For example, AtALMT4, AtALMT6, AtALMT9, and AtALMT12 in Arabidopsis and HvALMT1 in barley are expressed in guard cells and participate in the regulation of the stomatal aperture through anion transport [19,27-32]. In maize, ZmALMT1 is localized at the plasma membrane and transports inorganic anions rather than malate, while ZmALMT2 is permeable for malate, citrate, $\mathrm{Cl}^{-}$and $\mathrm{NO}_{3}{ }^{-}$[23,24]. Both ZmALMT1 and ZmALMT2 are involved in anion homeostasis. Recently, OsALMT4 is showed to be a malate permeable anions channel, which plays an important role in the growth of rice in low-light environments [33]. More and more studies indicate that ALMTs have multiple functions in plants, including toxic metal resistance, ion homeostasis, mineral nutrition, turgor regulation, pollen tube growth, and guard cell regulation [34]. Another organic acid efflux transporter family MATEs have been identified in barley (HvAACT1), sorghum (SbMATE1), wheat (TaMATE1), Arabidopsis (AtMATE1), rye (ScFRDL2), maize (ZmMATE1), and rice (OsFRDL2 and OsFRDL4) [35-42]. They function as a plasma membrane efflux transporter and are responsible for the Al-activated citrate release. In addition to citrate and malate, buckwheat has been shown to secrete oxalate to chelate $\mathrm{Al}$ in the rhizosphere, but transporters for oxalate release in respond to Al have not been identified [43-45].

Table 1. The list of Al tolerance genes identified in plants.

\begin{tabular}{|c|c|c|c|}
\hline Genes & Plant Species & Functions & References \\
\hline AtALMT1 & Arabidopsis thaliana & Transport malate & [17] \\
\hline AtALS3 & Arabidopsis thaliana & Transport Al away from sensitive tissue & [46] \\
\hline AtMATE & Arabidopsis thaliana & Transport citrate & [36] \\
\hline AtNIP1;2 & Arabidopsis thaliana & Transported Al-malate into cytoplasm & [47] \\
\hline AtSTOP1 & Arabidopsis thaliana & Regulate $\mathrm{Al}$ tolerance genes & [48] \\
\hline AtWRKY46 & Arabidopsis thaliana & Regulate Al tolerance genes & [49] \\
\hline AtXET31 & Arabidopsis thaliana & Function in cell wall extension & [50] \\
\hline BnALMT1/2 & Brassica napus & Transport malate & [16] \\
\hline CcSTOP1 & Cajanus cajan & Homolog of AtSTOP1 & [51] \\
\hline FeALS1.1 & Fagopyrum esculentumMoench. & Homolog of OsALS1 & [52] \\
\hline FeALS1.2 & Fagopyrum esculentumMoench. & Homolog of OsALS1 & {$[52]$} \\
\hline GmALMT1 & Glycine $\max$ & Transport malate & [21] \\
\hline GmSTOP1-1 & Glycine max & Homolog of AtSTOP1 & [53] \\
\hline GmSTOP1-1 & Glycine max & Homolog of AtSTOP1 & [53] \\
\hline GmSTOP1-3 & Glycine max & Homolog of AtSTOP1 & [53] \\
\hline HlALMT1 & Holcus lanatus & Transport malate & [54] \\
\hline HIART1 & Holcus lanatus & Homolog of OsART1 & [25] \\
\hline HmPALT1 & Hydrangea macrophylla & Transport Al into the cytoplasm & [55] \\
\hline HmVALT1 & Hydrangea macrophylla & Sequester $\mathrm{Al}$ into the vacuoles & [55] \\
\hline HvAACT1 & Hordeum vulgare L. & Transport citrate & [56] \\
\hline MsALMT1 & Medicago sativa & Transport malate & [26] \\
\hline NtSTOP1 & Nicotiana tabacum & Homolog of AtSTOP1 & [54] \\
\hline OsALS1 & Oryza sativa & Sequester $\mathrm{Al}$ into the vacuoles & [57] \\
\hline OsART1 & Oryza sativa & Regulate $\mathrm{Al}$ tolerance genes & [58] \\
\hline OsART2 & Oryza sativa & Regulate $\mathrm{Al}$ tolerance genes & [59] \\
\hline OsASR1 & Oryza sativa & Regulate $\mathrm{Al}$ tolerance genes & [60] \\
\hline OsASR5 & Oryza sativa & Regulate $\mathrm{Al}$ tolerance genes & [61] \\
\hline OsCDT3 & Oryza sativa & Bind $\mathrm{Al}$ & [62] \\
\hline OsEXPA10 & Oryza sativa & Mediate cell wall loosening & [63] \\
\hline OsFRDL2 & Oryza sativa & Transport citrate & [39] \\
\hline OsFRDL4 & Oryza sativa & Transport citrate & [64] \\
\hline
\end{tabular}


Table 1. Cont.

\begin{tabular}{cccc}
\hline Genes & Plant Species & Functions & References \\
\hline OsMGT1 & Oryza sativa & Transport Mg into the cytoplasm & {$[65]$} \\
OsNrat1 & Oryza sativa & Transport Al into the cytoplasm & {$[66]$} \\
OsSTAR1 & Oryza sativa & Transport UDP-glucose to cell wall & {$[67]$} \\
OsSTAR2 & Oryza sativa & Transport UDP-glucose to cell wall & {$[67]$} \\
OsWRKY22 & Oryza sativa & Regulate Al tolerance genes & {$[68]$} \\
SbMATE1 & Sorghum bicolor L. & Transport citrate & {$[37]$} \\
SbSTOP1 & Sorghum bicolor L. & Homolog of AtSTOP1 & {$[69]$} \\
SbWRKY1 & Sorghum bicolor L. & Regulate Al tolerance genes & {$[70]$} \\
SbZNF1 & Sorghum bicolor L. & Regulate Al tolerance genes & {$[70]$} \\
ScALMT1 & Secale cereale L. & Transport malate & {$[18]$} \\
ScFRDL2 & Secale cereale L. & Transport citrate & {$[35]$} \\
TaALMT1 & Triticum aestivum L. & Transport malate & {$[15]$} \\
TaMATE1 & Triticum aestivum L. & Transport citrate & {$[41]$} \\
TaMATE1B & Triticum aestivum L. & Transport citrate & {$[71]$} \\
TaSTOP1 & Triticum aestivum L. & Homolog of AtSTOP1 & {$[72]$} \\
VuSTOP1 & Vigna umbellata & Homolog of AtSTOP1 & {$[73]$} \\
ZmMATE1 & Zea mays & Transport citrate & {$[42]$} \\
\hline
\end{tabular}

In response to $\mathrm{Al}$ stress, organic acid is secreted from the root cells to chelate $\mathrm{Al}$ in two distinct patterns $[74,75]$. In the first pattern, no discernible delay can be observed between the initiation of organic acid secretion and $\mathrm{Al}$ addition in barley and wheat $[76,77]$. In the second pattern, an obvious delay (several hours to days) between $\mathrm{Al}$ exposure and the secretion of organic acid is observed in sorghum, rye, maize, Arabidopsis, and rice [17,35,37,40,42]. The rapid secretion of organic acid following exposure to $\mathrm{Al}$ in the first pattern suggests that organic acid secretion does not require the induction of genes encoding organic acid transporters such as TaALMT1 and HvAACT1. The presence of external $\mathrm{Al}$ enables and/or enhances organic acid release from the root cells. However, in the second pattern, a distinct lag between $\mathrm{Al}$ exposure and the secretion of organic acids, and/or the expression of organic acid transporters are observed. Three possibilities have been proposed to explain the variable patterns [78]: (i) External Al directly interacts with the transporter, leading to its conformational change and the increase of its mean conductance or open time. This is analogous to ligand-gated channels. (ii) Al binds to specific membrane receptors through the signal transduction pathways in the cytoplasm to regulate the channel activity. (iii) $\mathrm{Al}$ enters the cytoplasm and directly or indirectly activates or enhances the activity of organic acid transporters. It has recently been shown that $\mathrm{Al}$ enhances the activity of organic acid transporters. The transport activity of TaALMT1, AtAMLT1, OsFRDL4, and HvAACT1 is enhanced by exogenous $\mathrm{Al}$ in Xenopus oocytes [17,38,40,79]. To date, researchers have mainly focused on the mechanism underlying Al activation of ALMTs activity. ALMT1 protein is composed of an $\mathrm{N}$-terminus region containing six transmembrane domains and a variable long hydrophilic C terminus [30]. Three main residues (Glu274, Asp275, and Glu284) in C terminus of TaALMT1 are shown to be required for Al-dependent transport enhancement [80]. However, Ligaba et al. [81] reported that both $\mathrm{N}$ - and C-terminus regions are involved in Al enhancement of transport activity. Recently, ALMT activity has also been found to be negatively regulated by c-aminobutyric acid (GABA) [82]. Sequence analysis suggested that ALMTs contain a GABA-binding motif with homology to the one presented in the $\mathrm{GABA}_{\mathrm{A}}$ receptor, which plays a critical role in the relationship between malate efflux and endogenous GABA concentrations, as well as in GABA transport by ALMTs $[82,83]$. However, the regulatory mechanism of ALMT1 transport activity by Al and GABA is still poorly understood. The crystal structural studies of ALMT1 will be required to understand the conformational changes of the ALMTs upon interaction with Al or GABA and the underlying mechanism.

Not only organic acids chelate Al. Other organic compounds are also reported to have the capacity to chelate trivalent $\mathrm{Al}$ ions, such as phenolics and benzoxazinoids. Kidd et al. [84] found that maize secretes the phenolic compounds catechol, catechin, and quercetin to chelate Al. Hydroxide radicals in 
these phenolic compounds provide potential targets for $\mathrm{Al}$ ion chelation, although phenolic compounds are less effective chelators compared to organic acids [4]. Recently, Al- and salicylic-acid-activated root efflux of benzoxazinoids (HA) has been demonstrated to chelate $\mathrm{Al}$ and enhance $\mathrm{Al}$ tolerance in maize [85]. However, genes involved in Al-induced secretion of phenolics and benzoxazinoids have not been identified in any plant species yet.

The increase in rhizosphere $\mathrm{pH}$ is another $\mathrm{Al}$ exclusion mechanism in plants. Elevation in the rhizosphere $\mathrm{pH}$ can lower the solubility, activity, and potential toxicity of $\mathrm{Al}$, thus achieving higher tolerance to $\mathrm{Al}$ for plants [86-88]. For instance, an Al-tolerant mutant alr-104 exhibits an Al-induced increase in rhizosphere $\mathrm{pH}$ through the increased $\mathrm{H}^{+}$influx in Arabidopsis [87]. In other plant species (wheat, buckwheat), the Al-tolerant lines can maintain a relatively higher $\mathrm{pH}$ surrounding the root apex than Al-sensitive lines $[44,86]$. $\mathrm{PM} \mathrm{H}^{+}$-ATPase has been shown to be involved in regulating rhizosphere $\mathrm{pH}$ [86-88]. Additionally, the secretion of organic acids from the root apex to the rhizosphere can also modify rhizosphere $\mathrm{pH}$ in the presence of $\mathrm{Al}$ [88].

\section{Al Tolerance Mechanisms}

Trivalent $\mathrm{Al}$ ions display severe phytotoxicity to many cereal crops (rice, wheat, maize, buckwheat, and rye), and micromolar levels of Al rapidly inhibit root elongation. Once Al enters the plant, highly Al-tolerant cereal species employ multiple genes and mechanisms to be involved in Al tolerance at different levels in the roots. To date, $\mathrm{Al}$ tolerance mechanisms mainly include cell wall modification, the uptake and subsequent sequestration of $\mathrm{Al}$, and root-to-shoot translocation of $\mathrm{Al}$ [14].

Considering that the cell wall contains most $\mathrm{Al}$ amongst the whole roots $[7,89,90]$, it is reasonable that plants cope with Al stress through cell wall modifications. The primary root cell wall is mainly composed of cellulose, pectins, and hemicelluloses [91]. Cellulose is made up of unbranched 1,4 $\beta-D$ glucan chains and is considered not to bind $\mathrm{Al}$, while both pectins with the negatively charged carboxyl groups and hemicelluloses with highly branched structures can interact with $\mathrm{Al}^{3+}$ ions [91,92]. The negatively charged carboxyl groups of pectins can crosslink with $\mathrm{Ca}^{2+}$ ions. However, trivalent $\mathrm{Al}^{3+}$ ions have stronger binding to pectins than $\mathrm{Ca}^{2+}$. Under $\mathrm{Al}$ stress, replacement of pectin-bound $\mathrm{Ca}^{2+}$ ions by $\mathrm{Al}$ makes the cell wall thicker and more rigid, thus inhibiting cell extension and division [93]. The highly methylated pectins by pectin methylesterases (PMEs) are converted to negatively charged demethylation form, leading to more Al binding to pectins. Al-tolerant cultivars exhibiting a higher methylated pectin proportion and lower PME activity are found in rice, maize, and buckwheat $[89,92,94]$. Furthermore, OsPME14-overexpressed lines showed more $\mathrm{Al}$ accumulation in root tip cell wall and increased sensitivity to $\mathrm{Al}$ [95]. On the other hand, hemicelluloses were also shown to be a major site for $\mathrm{Al}$ accumulation, significantly contributing to $\mathrm{Al}$ adsorption and root growth in Arabidopsis [92]. The hemicellulose (xyloglucan)-cellulose network is catalyzed by xyloglucan endohydrolase (XEH) and xyloglucan endotransglucosylase (XET) encoded by xyloglucan endotransglucosylase-hydrolase (XTH) genes, which are involved in cell expansion by cutting and rejoining of xyloglucan chains. XTH gene expression and enzyme activity are influenced by hormonal and environmental stimuli [91]. Plant hormones such as auxins and gibberellins can increase the expression and activity of XTH while Al represses it [50,96,97]. Zhu et al. [50] reported that Al inhibited the expression and activity of XTH31 in Arabidopsis roots and mutation of XTH31 enhanced Al tolerance by reducing cell wall xyloglucan content and lowering its Al binding capacity. In rice, OsSTAR1 (for sensitive to Al rhizotoxicity 1) encodes a nucleotide binding domain, while OsSTAR2 encodes a transmembrane domain. OsSTAR1 and OsSTAR2 together form a complex that functions as a vesicle membrane-localized ABC transporter in roots and transports UDP-glucose into the cell wall, which may modify the cell wall and mask the sites through which $\mathrm{Al}$ can bind, reducing $\mathrm{Al}$ accumulation and damage in the cell wall [67].

In plants, several types of transporters have been shown to be involved in the uptake and subsequent sequestration and root-to-shoot translocation of $\mathrm{Al}$ in plants (Table 1). In rice, OsNrat1 (Nramp aluminum transporter 1) encodes a plasma membrane-localized transporter belonging to 
the Nramp (natural resistance-associated macrophage protein) family, showing low similarity to other Nramp members. OsNrat1 does not transport divalent metals $\left(\mathrm{Mn}^{2+}, \mathrm{Fe}^{2+}, \mathrm{Cd}^{2+}\right)$ as other Nramp members, but specifically transports trivalent $\mathrm{Al}$ ions and plays an important role in rice Al tolerance [66]. Bioinformatic and functional analysis identify Ala-Ile-Ile-Thr motifs as a key determinant of Al selectivity for Nrat1 [98]. On the other hand, OsALS1 is a tonoplast-localized ATP-binding cassette $(\mathrm{ABC})$ transporter responsible for sequestrating $\mathrm{Al}$ into the vacuoles in the roots [57]. Knockout of OsALS1 in rice led to significant hypersensitivity to Al, suggesting that OsALS1 is required for rice internal $\mathrm{Al}$ detoxification. Homologs of OsALS1 (FeALS1.1 and FeALS1.2) in buckwheat have also been identified, which are implicated in vacuolar sequestration of Al [52]. Since OsNrat1 and OsALS1 share similar expression and localization patterns, these two proteins function cooperatively; i.e., Nrat1 mediates cell entry of $\mathrm{Al}$, and $\mathrm{Al}$ is sequestered into vacuoles by OsALS1, thus mediating Al detoxification in rice roots [57,66]. In Arabidopsis, AtALS3 (Aluminum sensitive 3) is an ABC-transporter primarily expressed in the phloem of roots, leaves, stems, and flowers [46]. AtALS3 is suggested to function as a $\mathrm{Al}$ transporter and redistribute accumulated $\mathrm{Al}$ away from sensitive tissues to protect the sensitive root tip from Al toxicity. Recently, two members of the aquaporin (AQP) family in Hydrangea macrophylla, HmPALT1, and HmVALT1 have been reported to encode plasma membrane and vacuolar $\mathrm{Al}$ transporters, respectively [55]. Although the $\mathrm{Al}$ form transported by these two transporters remains unclear, they facilitate to transport $\mathrm{Al}$ into the cytosol and vacuoles in Hydrangea. More recently, NIP1;2, the closest homolog of HmPALT1, was identified as a bidirectional Al-malate transporter functioning in $\mathrm{Al}$ removal from root cell walls and root-to-shoot $\mathrm{Al}$ translocation in Arabidopsis [47]. Furthermore, Al-malate transport of NIP1;2 is dependent on Al-activated malate release mediated by AtALMT1 in roots. Hence, a coordinated operation between external and internal Al detoxification mechanisms was linked by NIP1;2 and AtALMT1.

In comparison to most plant species such as rice and Arabidopsis, a small fraction of plant species, including buckwheat, hydrangea, tea, and melastoma malabatbricum, are able to translocate and accumulate $\mathrm{Al}$ at a high level in aerial parts without showing obvious toxicity symptoms [45,99-102]. Some studies have revealed that small organic compounds play key roles in the uptake, translocation, accumulation, and internal detoxification of $\mathrm{Al}$ in these Al-accumulating plants. For example, in buckwheat, $\mathrm{Al}$ is taken up in the ionic form and chelated with internal oxalate in root cells, forming a nontoxic Al-oxalate complex at a 1:3 ratio. During the root-to-shoot Al translocation, Al-oxalate (1:3) is converted to Al-citrate (1:1) in the xylem. When Al-citrate is transported into the vacuoles of the leaf cells, Al-citrate is changed back to Al-oxalate [45,99]. In hydrangea, $\mathrm{Al}$ is found to be complexed with delphinidin 3-glucoside and 3-caffeoylquinic in the sepals and with citrate at a 1:1 ratio in the leaves [100]. $\mathrm{Al}$ is also demonstrated to be chelated with catechin in tea leaves [103]. These studies indicate that internal detoxification of $\mathrm{Al}$ in the $\mathrm{Al}$-accumulating plants is achieved by formation of nonphytotoxic $\mathrm{Al}$ complexes with small organic compounds and by sequestrating $\mathrm{Al}$ into the vacuoles of the leaf cells.

Direct $\mathrm{Al}$ transport is not the only way to mediate $\mathrm{Al}$ detoxification. It has been shown that the transport of $\mathrm{Mg}$ could also relieve $\mathrm{Al}$ phytotoxicity. OsMGT1 (Magnesium transporter 1) is a plasma membrane-localized transporter for $\mathrm{Mg}$ in rice. Chen et al. [65] found that knockout of this gene significantly decreased $\mathrm{Mg}$ uptake and increased the sensitivity to $\mathrm{Al}$ in rice, and an $\mathrm{Al}$-sensitive phenotype in knockout lines under $\mathrm{Al}$ treatment could be recovered by exogenous micromolar $\mathrm{Mg}$ supply. One hypothesis is that the increased $\mathrm{Mg}$ concentration in the cytosol contributes to the competitive inhibition of potential targets of Al such as DNA, RNA, ATP, inorganic phosphate, proteins, and other cellular components [65]. This finding proposed a possible mechanism for plants to detoxify internal $\mathrm{Al}$ by means of competitive inhibition with increasing $\mathrm{Mg}$ uptake into the cells.

\section{Transcriptional Regulation of Al Tolerance Genes}

Transcription factors like zinc finger protein, MYB, WRKY, NAC, and bZIP families act as the early responders to environmental signals and modulate the expression of downstream genes that 
are required for plants to adapt to abiotic stresses [104]. Two kinds of transcription factors, $\mathrm{C}_{2} \mathrm{H}_{2}$-type zinc finger protein and WRKY, were reported to play important roles in regulating $\mathrm{Al}$ tolerance gene expression (Table 1). In Arabidopsis, AtSTOP1 belongs to the $\mathrm{C}_{2} \mathrm{H}_{2}$-type zinc finger transcription factor family functioning in both proton and $\mathrm{Al}$ tolerance [48]. The expression of AtSTOP1 was unaffected by exogenous $\mathrm{Al}$, but the expression of several Al-tolerance genes regulated by AtSTOP1, including AtALS3, AtALMT1, and AtMATE1, was induced by Al $[46,105,106]$. Therefore, the involvement of AtSTOP1 in $\mathrm{Al}$ induction of gene expression might be regulated by $\mathrm{Al}$ at posttranscriptional or posttranslational levels. Recently, an F-box protein, RAE1, was found to regulate AtSTOP1 stability, which can interact with and regulate AtSTOP1 degradation via the ubiquitin-26S proteasome pathway [107].

OsART1, a homolog of AtSTOP1, plays a similar function in rice [58]. It is localized to the nucleus and is constitutively expressed in all root cells with or without Al treatment. But unlike AtSTOP1, it specifically functions in Al tolerance. Microarray analysis suggested that at least 31 Al-responsive genes are regulated by OsART1, which are involved in both internal and external detoxification of $\mathrm{Al}$ in rice. Among them, ten genes have been functionally characterized. These included OsSTAR1, OsSTAR2, OsNrat1, OsALS1, OsMGT1, OsFRDL4, and OsFRDL2, which are discussed above as rice Al tolerance genes $[39,40,65-67,98]$. The other three genes are OsCDT3, OsEXPA10, and OsART2 [59,62,63]. $\mathrm{OsCDT} 3$ is a small cysteine-rich peptide localized on the plasma membrane and may prevent $\mathrm{Al}$ entry into root cells through direct $\mathrm{Al}$ binding, therefore, contributing to rice $\mathrm{Al}$ tolerance [62]. OsEXPA10 is one of the expansin genes up-regulated by $\mathrm{Al}$ and is involved in normal root cell elongation, but its contribution to $\mathrm{Al}$ tolerance is small [63]. OsART2, a homolog of OsART1, is highly induced by $\mathrm{Al}$. The knockout of OsART2 resulted in increased sensitivity to $\mathrm{Al}$ in rice [59]. However, OsART2 contributes more modestly to Al tolerance than OsART1. RNA-sequencing analysis showed that four genes implicated in Al tolerance are regulated by OsART2 and do not overlap with the genes regulated by OsART1, indicating that OsART1 and OsART2 regulate different pathways involved in rice $\mathrm{Al}$ tolerance.

Recently, homologs of OsART1/AtSTOP1 have also been identified in other plant species, such as in Yorkshire fog (HIART1), wheat (TaSTOP1), tobacco (NtSTOP1), rice bean (VuSTOP1), pigeon pea (CcSTOP1), soybean (GmSTOP1), and sorghum (SbSTOP1) $[25,51,53,54,69,72,73]$. These OsART1/AtSTOP1-like proteins from different species or even from one species play different roles in $\mathrm{Al}$ and $\mathrm{H}^{+}$tolerance, although these proteins possessed a highly conserved $\mathrm{Cys}_{2} \mathrm{His}_{2}$ zinc finger domain. For example, NtSTOP1 is involved in both Al tolerance and proton tolerance in tobacco while VnSTOP1 only functions in proton tolerance in rice bean. In soybean, all three GmSTOP1s function in proton tolerance, but only GmSTOP1-1 and GmSTOP1-3 regulate Al tolerance. The exact mechanism for such different roles requires further investigations.

In higher plants, the WRKY transcription factor is characterized by the presence of specific WRKY domains that bind to W-box sequences ( $(\mathrm{T} / \mathrm{C}) \mathrm{TGAC}(\mathrm{T} / \mathrm{C})$ ) in the promoter region of the candidate regulated genes. In Arabidopsis, AtWRKY46, a member of the WRKY transcription factor family, was reported to function as a transcriptional repressor of AtALMT1 [49]. The expression of AtWRKY46 colocalizes with that of AtALMT1 in roots. Under Al stress, AtWRKY46 expression is decreased while AtALMT1 expression is increased. Mutation of AtWRKY46 promotes the expression of AtALMT1, root malate secretion, and Al tolerance. Furthermore, AtWRKY46 binds to W-box sequences in the AtWRKY46 promoter. These findings indicate that AtWRKY46 is a negative regulator of AtALMT1 expression. Recently, OsWRKY22, another member of the WRKY transcription factor family, has been identified to be involved in $\mathrm{Al}$ tolerance in rice [68]. In contrast to AtWRKY46, OsWRKY22 is a positive regulator of rice $\mathrm{Al}$ tolerance. In response to $\mathrm{Al}$, OsWRKY22 promotes $\mathrm{Al}$-induced OsFRDL4 expression by binding to W-box cis elements within the promoter of OsFRDL4, resulting in enhancing $\mathrm{Al}$-induced citrate secretion and $\mathrm{Al}$ tolerance in rice. Furthermore, OsWRKY22 cooperates with ART1 to regulate Al-induced expression of OsFRDL4 and citrate secretion. More recently, both SbWRKY1 and a DHHC-type zinc finger transcription SbZNF1 are reported to trans-activate SbMATE expression 
through binding to MITE repeat cis elements within SbMATE promoter in sorghum [70]. Interestingly, SbMATE expression is highly correlated with sorghum $\mathrm{Al}$ tolerance, which is found to be regulated by both the number of MITE repeats and the expression level of SbWRKY1 and SbZNF1. These findings provide a potential strategy for improving plant $\mathrm{Al}$ tolerance in acidic soils by means of finetuning the concerted cis-trans interactions.

In addition to OsART1/AtSTOP1 and WRKY transcription factor, two ASR genes (ABA-stress and ripening), OSASR1 and OSASR5, have also been proposed to be involved in Al tolerance in rice $[60,61,108,109]$. Both OsASR1 and OsASR5 are localized in the cytoplasm and nucleus and function as transcription factors to regulate OSSTAR1 expression through binding to its promoter region. They have compensatory and complementary functions in $\mathrm{Al}$ tolerance. However, down-regulation of OsASR5 by RNAi also decreased tolerance to drought stress and displayed some morphologic changes, indicating that OsASR5 has other potential roles in environmental stresses and plant development.

Other studies regarding the transcriptional regulation of $\mathrm{Al}$ tolerance genes focused on alterations in the promoter region and copy number of genes. In wheat, the constitutively high expression of TaALMT1 in Al-tolerant lines is associated with duplicated and triplicated tandem repeats in the promoter region [110]. In sorghum, the higher SbMATE1 expression is associated with more repeat number of MITEs (tourist-like miniature inverted repeat transposable elements) in the SbMATE1 promoter [37]. A transposable element insertion in the promoter of MATE/AACT genes is also found to enhance their expression in barley (HvAACT1), wheat (TaMATE1B), and rice (OsFRDL4) [64,71,111]. In Yorkshire fog (Holcus lanatus), higher HIALMT1 expression in an Al-tolerant accession is attributed to an increased number of HIART1 cis-acting elements in its promoter [25]. Additionally, the elevated expression for ZmALMT1 in maize and ScALMT1 in rye is caused by their increased copy number in the genome $[18,112]$. These findings revealed that different mechanisms are involved in regulating the expression of ALMT and MATE, including increased tandem repeated elements, transposable element insertion, increased copy number, and increased number of cis-acting elements.

\section{MicroRNA Mediates Al Tolerance}

MicroRNAs (miRNA) are small non-coding RNAs with an important role in regulating gene expression by silencing their complementary mRNA targets and translational repression, which participate in numerous biological processes including development, metabolism, and biotic and abiotic stress responses in higher plants. Several studies have shown that miRNAs are involved in the plant response to Al stress. Lima et al. [113] reported that miRNA168, miRNA528, and miRNA399 are up-regulated in rice roots of both japonica and indica varieties under Al stress while only miRNA395 is down-regulated. In wild soybean, 30 miRNAs were identified to be responsive to Al stress [114]. Recently, comparative miRNA expression analysis between Al-tolerant Tibetan wild barley and Al-sensitive cultivated barley identified 50 Al-responsive miRNAs [115]. Among them, some miRNAs, such as miR160, MiR393, and PC-miR1, were found to be exclusively expressed in Al-tolerant Tibetan wild barley and related to $\mathrm{Al}$ tolerance. Based on degradome identification and bioinformatics analysis, target genes of the above-mentioned miRNAs in different plant species participated in an array of cellular processes including auxin-response pathways, ROS detoxification, cell wall modification, and nutrient and carbon metabolism. Details on how the miRNAs regulate downstream gene expression involved in $\mathrm{Al}$ tolerance requires further investigation in future studies.

\section{Arbuscular Mycorrhizas Mediates Al Tolerance}

The roots of most higher plants are associated with soil microorganisms that directly or indirectly affect plant growth and development. Among these microflora, arbuscular mycorrhizal (AM) fungi are reported to play a key role in enhancing plant tolerance to diverse abiotic stresses in soil, including Al toxicity [116]. For example, Rufyikiri et al. [117] reported that AM fungi could be effective in alleviating Al toxicity to banana plants. Inoculation with AM fungi and saprobe fungi combinations can improve Al tolerance in Eucalyptus globulus [118]. Recently, an early colonization with AM fungi 
is found to be an important factor in protecting wheat from Al toxicity [119]. Previous studies have revealed several possible mechanisms of Al tolerance induced by AM fungi in higher plants, including that (a) AM fungi improve the uptake of phosphorus (P) and other nutrients in their host plants through the interaction Al-P in colonized roots, which is critical in maintaining plant growth under Al stress [116,120,121]; (b) AM fungi stimulate the processing of carbon in roots through the citric acid cycle to enhance the exudation of organic acids, which chelates $\mathrm{Al}^{3+}$ in the rhizosphere [116]; (c) glomalin-related soil protein (GRSP) produced by AM fungi has the capacity to sequester $\mathrm{Al}^{3+}$ in the rhizosphere [116,122]; (d) AM fungal structures such as spores and hyphae have the capacity to bind $\mathrm{Al}$ directly or build an enlarged mycorrhizosphere in which $\mathrm{Al}$ is detoxified [123-126]. Further details on the role of AM fungi in improving $\mathrm{Al}$ tolerance in higher plants require investigation in future studies.

\section{Conclusions and Remarks}

Over recent decades, substantial progress has been made in the understanding of physiological and molecular mechanisms of Al tolerance in higher plants. To date, the vast array of genes involved in Al tolerance such as MATE, ALMT, and ABC transporters have been identified in different species (Table 1). Transcription factors that regulate these genes, including ART1/STOPs and WRKYs, have also been identified in different species (Table 1). The mechanisms by which Al regulates these transcription factors are still however unknown. For example, expression of OsART1 and AtSTOP1 is not affected by $\mathrm{Al}$ but their downstream genes are induced by $\mathrm{Al}$ treatment. It will be interesting to investigate how OsART1 and AtSTOP1 are activated to regulate the transcription of Al tolerance genes by Al. Furthermore, how plants cells sense and signal $\mathrm{Al}$ from the rhizosphere is still unclear, and the identification of plasma membrane-localized sensor specific responses to $\mathrm{Al}$ is required to illuminate the signal transduction pathways intracellularly induced in response to Al toxicity. MicroRNA is a relatively new research area and studies in this area require more focuses to identify the role of miRNAs in gene regulation under Al stress. The rapid development of whole-genome sequencing and the genome-editing technology provides new opportunities for unraveling these mechanisms and identifying novel ones.

Identification of Al tolerance genes and mechanisms makes it possible to breed Al-tolerant crop species and cultivars via molecular breeding and transgenic approaches. To date, ALMT and MATE genes have been used to improve the $\mathrm{Al}$ tolerance in sorghum, barley, and wheat $[37,127,128]$. However, there are some limitations of the present methods to introduce single genes into $\mathrm{Al}$-sensitive species and cultivars. For instance, barley transformed with HvAACT1 displayed lower tolerance to $\mathrm{Al}$ than Al-tolerant barley cultivar, Dayton [56]. Furthermore, Al tolerance in some crop species is controlled by multiple genes. Therefore, introduction of multiple Al tolerance genes should be developed for enhancing Al tolerance and improving crop yields on acid soils through conventional breeding and modern biotechnology. On the other hand, the use of diverse AM fungal species adapted to a high Al presence should be considered as an important way to alleviate the Al toxicity and increase crop yields in acidic soils.

Author Contributions: X.Z., Y.L., J.H. and J.X. wrote the review; J.X. conceived the review.

Funding: The work was funded by National Natural Science Foundation of China (31670253), Guangxi Natural Science Foundation (2016GXNSFFA380013), Guangxi innovation-driven development special funding project (Grant no. Guike-AA17204070), and the Project of High Level Innovation Team and Outstanding Scholar in Guangxi Colleges and Universities (2016).

Acknowledgments: We thank Zhenhua Ming (Guangxi University) for critically reading the manuscript.

Conflicts of Interest: The authors declare no conflict of interest. 


\section{References}

1. Von Uexküll, H.R.; Mutert, E. Global extent, development and economic impact of acid soils. Plant Soil 1995, 171, 1-15. [CrossRef]

2. Rengel, Z. Disturbance of cell $\mathrm{Ca}^{2+}$ homeostasis as a primary trigger of $\mathrm{Al}$ toxicity syndrome. Plant Cell Environ. 1992, 15, 931-938. [CrossRef]

3. Ryan, P.R.; Delhaize, E.; Jones, D.L. Function and mechanism of organic anion exudation from plant roots. Annu. Rev. Plant Physiol. Plant Mol. Biol. 2001, 52, 527-560. [CrossRef] [PubMed]

4. Barcelo, J.; Poschenrieder, C. Fast root growth responses, root exudates, and internal detoxification as clues to the mechanisms of aluminium toxicity and resistance: A review. Environ. Exp. Bot. 2002, 48, 75-92. [CrossRef]

5. Kochian, L.V.; Piñeros, M.A.; Hoekenga, O.A. The physiology, genetics and molecular biology of plant aluminum resistance and toxicity. Plant Soil. 2005, 274, 175-195. [CrossRef]

6. Ma, J.F. Syndrome of aluminum toxicity and diversity of aluminum resistance in higher plants. Int. Rev. Cytol. 2007, 264, 225-252. [PubMed]

7. Ma, J.F.; Shen, R.; Nagao, S.; Tanimoto, E. Aluminum targets elongating cells by reducing cell wall extensibility in wheat roots. Plant Cell Physiol. 2004, 45, 583-589. [CrossRef] [PubMed]

8. Guo, P.; Qi, Y.P.; Yang, L.T.; Lai, N.W.; Ye, X.; Yang, Y.; Chen, L.S. Root adaptive responses to aluminum-treatment revealed by RNA-Seq in two citrus species with different aluminum-tolerance. Front. Plant Sci. 2017, 8, 330. [CrossRef]

9. Dai, H.; Cao, F.; Chen, X.; Zhang, M.; Ahmed, I.M.; Chen, Z.H.; Li, C.; Zhang, G.; Wu, F. Comparative proteomic analysis of aluminum tolerance in tibetan wild and cultivated barleys. PLoS ONE 2013, 8, e63428. [CrossRef]

10. Sivaguru, M.; Baluška, F.; Volkmann, D.; Felle, H.H.; Horst, W.J. Impacts of aluminum on the cytoskeleton of the maize root apex. short-term effects on the distal part of the transition zone. Plant Physiol. 1999, 119, 1073-1082. [CrossRef]

11. Ma, B.; Gao, L.; Zhang, H.; Cui, J.; Shen, Z. Aluminum-induced oxidative stress and changes in antioxidant defenses in the roots of rice varieties differing in Al tolerance. Plant Cell Rep. 2012, 31, 687-696. [CrossRef]

12. Liu, J.; Piñeros, M.A.; Kochian, L.V. The role of aluminum sensing and signaling in plant aluminum resistance. J. Integr. Plant Biol. 2014, 56, 221-230. [CrossRef] [PubMed]

13. Ma, J.F.; Chen, Z.C.; Shen, R.F. Molecular mechanisms of Al tolerance in gramineous plants. Plant Soil 2014, 381, 1-12. [CrossRef]

14. Kochian, L.V.; Piñeros, M.A.; Liu, J.; Magalhaes, J.V. Plant adaptation to acid soils: The molecular basis for crop aluminum resistance. Annu. Rev. Plant Biol. 2015, 66, 571-598. [CrossRef]

15. Sasaki, T.; Yamamoto, Y.; Ezaki, B.; Katsuhara, M.; Ahn, S.J.; Ryan, P.R.; Delhaize, E.; Matsumoto, H. A wheat gene encoding an aluminum-activated malate transporter. Plant J. 2004, 37, 645-653. [CrossRef] [PubMed]

16. Ligaba, A.; Katsuhara, M.; Ryan, P.R.; Shibasaka, M.; Matsumoto, H. The BnALMT1 and BnALMT2 genes from rape encode aluminum-activated malate transporters that enhance the aluminum resistance of plant cells. Plant Physiol. 2006, 142, 1294-1303. [CrossRef]

17. Hoekenga, O.A.; Maron, L.G.; Piñeros, M.A.; Cancado, G.M.A.; Shaff, J.; Kobayashi, Y.; Ryan, P.R.; Dong, B.; Delhaize, E.; Sasaki, T.; et al. AtALMT1, which encodes a malate transporter, is identified as one of several genes critical for aluminum tolerance in Arabidopsis. Proc. Natl. Acad. Sci. USA 2006, 103, 9738-9743. [CrossRef] [PubMed]

18. Collins, N.C.; Shirley, N.J.; Saeed, M.; Pallotta, M.; Gustafson, J.P. An ALMT1 gene cluster controlling aluminum tolerance at the Alt4 locus of rye (Secale cereale L). Genetics 2008, 179, 669-682. [CrossRef] [PubMed]

19. Gruber, B.D.; Ryan, P.R.; Richardson, A.E.; Tyerman, S.D.; Ramesh, S.; Hebb, D.M.; Howitt, S.M.; Delhaize, E. HvALMT1 from barley is involved in the transport of organic anions. J. Exp. Bot. 2010, 61, 1455-1467. [CrossRef]

20. Peng, W.; Wu, W.; Peng, J.; Li, J.; Lin, Y.; Wang, Y.; Tian, J.; Sun, L.; Liang, C.; Liao, H. Characterization of the soybean GmALMT family genes and the function of GmALMT5 in response to phosphate starvation. J. Integr. Plant Biol. 2018, 60, 216-231. [CrossRef] 
21. Liang, C.; Piñeros, M.A.; Tian, J.; Yao, Z.; Sun, L.; Liu, J.; Shaff, J.; Coluccio, A.; Kochian, L.V.; Liao, H. Low $\mathrm{pH}$, aluminum, and phosphorus coordinately regulate malate exudation through GmALMT1 to improve soybean adaptation to acid soils. Plant Physiol. 2013, 161, 1347-1361. [CrossRef]

22. Liu, J.; Zhou, M.; Delhaize, E.; Ryan, P.R. Altered expression of a malate-permeable anion channel, OsALMT4, disrupts mineral nutrition. Plant Physiol. 2017, 175, 1745-1759. [CrossRef] [PubMed]

23. Piñeros, M.A.; Cancado, G.M.A.; Maron, L.G.; Lyi, S.M.; Menossi, M.; Kochian, L.V. Not all ALMT1-type transporters mediate aluminum-activated organic acid responses: The case of ZmALMT1-An anion-selective transporter. Plant J. 2008, 53, 352-367. [CrossRef] [PubMed]

24. Ligaba, A.; Maron, L.; Shaff, J.; Kochian, L.; Piñeros, M. Maize ZmALMT2 is a root anion transporter that mediates constitutive root malate efflux. Plant Cell Environ. 2012, 35, 1185-1200. [CrossRef]

25. Chen, Z.C.; Yokosho, K.; Kashino, M.; Zhao, F.J.; Yamaji, N.; Ma, J.F. Adaptation to acidic soil is achieved by increased numbers of cis-acting elements regulating ALMT1 expression in Holcus lanatus. Plant J. 2013, 76, 10-23. [PubMed]

26. Chen, Q.; Wu, K.H.; Wang, P.; Yi, J.; Li, K.Z.; Yu, Y.X.; Chen, L.M. Overexpression of MsALMT1, from the aluminum-sensitive Medicago sativa, enhances malate exudation and aluminum resistance in tobacco. Plant Mol. Biol. Rep. 2013, 31, 769-774. [CrossRef]

27. Sasaki, T.; Mori, I.C.; Furuichi, T.; Munemasa, S.; Toyooka, K.; Matsuoka, K.; Murata, Y.; Yamamoto, Y. Closing plant stomata requires a homolog of an aluminum-activated malate transporter. Plant Cell Physiol. 2010, 51, 354-365. [CrossRef] [PubMed]

28. Meyer, S.; Mumm, P.; Imes, D.; Endler, A.; Weder, B.; Al-Rasheid, K.A.; Geiger, D.; Marten, I.; Martinoia, E.; Hedrich, R. AtALMT12 represents an R-type anion channel required for stomatal movement in Arabidopsis guard cells. Plant J. 2010, 63, 1054-1062. [CrossRef] [PubMed]

29. Meyer, S.; Scholz-Starke, J.; De Angeli, A.; Kovermann, P.; Burla, B.; Gambale, F.; Martinoia, E. Malate transport by the vacuolar AtALMT6 channel in guard cells is subject to multiple regulation. Plant J. 2011, 67, 247-257. [CrossRef]

30. Dreyer, I.; Gomez-Porras, J.L.; Riaño Pachón, D.M.; Hedrich, R.; Geiger, D. Molecular evolution of slow and quick anion channels (SLACs and QUACs/ALMTs). Front. Plant Sci. 2012, 3, 263. [CrossRef]

31. Xu, M.; Gruber, B.D.; Delhaize, E.; White, R.G.; James, R.A.; You, J.; Yang, Z.; Ryan, P.R. The barley anion channel, HvALMT1, has multiple roles in guard cell physiology and grain metabolism. Physiol. Plant 2015, 153, 183-193. [CrossRef]

32. De Angeli, A.; Zhang, J.; Meyer, S.; Martinoia, E. AtALMT9 is a malate-activated vacuolar chloride channel required for stomatal opening in Arabidopsis. Nat. Commun. 2013, 4, 1804. [CrossRef]

33. Liu, J.; Xu, M.; Estavillo, G.M.; Delhaize, E.; White, R.G.; Zhou, M.; Ryan, P.R. Altered expression of the malate-permeable anion channel OsALMT4 reduces the growth of rice under low radiance. Front. Plant Sci. 2018, 9, 542. [CrossRef] [PubMed]

34. Sharma, T.; Dreyer, I.; Kochian, L.; Piñeros, M.A. The ALMT family of organic acid transporters in plants and their involvement in detoxification and nutrient security. Front. Plant Sci. 2016, 7, 1488. [CrossRef]

35. Yokosho, K.; Yamaji, N.; Ma, J.F. Isolation and characterisation of two MATE genes in rye. Funct. Plant Biol. 2010, 37, 296-303. [CrossRef]

36. Liu, J.; Magalhaes, J.V.; Shaff, J.; Kochian, L.V. Aluminum-activated citrate and malate transporters from the MATE and ALMT families function independently to confer Arabidopsis aluminum tolerance. Plant J. 2009, 57, 389-399. [CrossRef] [PubMed]

37. Magalhaes, J.V.; Liu, J.; Guimaraes, C.T.; Lana, U.G.P.; Alves, V.M.C.; Wang, Y.H.; Schaffert, R.E.; Hoekenga, O.A.; Pineros, M.A.; Shaff, J.E.; et al. A gene in the multidrug and toxic compound extrusion (MATE) family confers aluminum tolerance in sorghum. Nat. Genet. 2007, 39, 1156-1161. [CrossRef]

38. Furukawa, J.; Yamaji, N.; Wang, H.; Mitani, N.; Murata, Y.; Sato, K.; Katsuhara, M.; Takeda, K.; Ma, J.F. An aluminum-activated citrate transporter in barley. Plant Cell Physiol. 2007, 48, 1081-1091. [CrossRef] [PubMed]

39. Yokosho, K.; Yamaji, N.; Miho, K.F.; Ma, J.F. Functional analysis of a MATE gene OsFRDL2 revealed its involvement in $\mathrm{Al}$-induced secretion of citrate, but less contribution to Al tolerance in rice. Plant Cell Physiol. 2016, 57, 976-985. [CrossRef]

40. Yokosho, K.; Yamaji, N.; Ma, J.F. An Al-inducible MATE gene is involved in external detoxification of Al in rice. Plant J. 2011, 68, 1061-1069. [CrossRef] 
41. Garcia-Oliveira, A.L.; Martins-Lopes, P.; Tolrá, R.; Poschenrieder, C.; Tarquis, M.; Guedes-Pinto, H.; Benito, C. Molecular characterization of the citrate transporter gene TaMATE1 and expression analysis of upstream genes involved in organic acid transport under $\mathrm{Al}$ stress in bread wheat (Triticum aestivum). Physiol. Plant 2014, 152, 441-452. [CrossRef] [PubMed]

42. Maron, L.G.; Piñeros, M.A.; Guimarães, C.T.; Magalhaes, J.V.; Pleiman, J.K.; Mao, C.; Shaff, J.; Belicuas, S.N.J.; Kochian, L.V. Two functionally distinct members of the MATE (multi-drug and toxic compound extrusion) family of transporters potentially underlie two major aluminum tolerance QTLs in maize. Plant J. 2010, 61, 728-740. [CrossRef] [PubMed]

43. Reuna-Llorens, I.; Corrales, I.; Poschenrieder, C.; Juan, B.; Cruz-Ortega, R. Both aluminum and ABA induce the expression of an abc-like transporter gene (FeALS3) in the Al-tolerant species fagopyrum esculentum. Environ. Exp. Bot. 2015, 111, 74-82. [CrossRef]

44. Wang, H.; Chen, R.F.; Iwashita, T.; Shen, R.F.; Ma, J.F. Physiological characterization of aluminum tolerance and accumulation in tartary and wild buckwheat. New Phytol. 2015, 205, 273-279. [CrossRef] [PubMed]

45. Ma, J.F.; Zheng, S.J.; Matsumoto, H. Detoxifying aluminium with buckwheat. Nature 1997, 390, 569-570. [CrossRef]

46. Larsen, P.B.; Geisler, M.J.B.; Jones, C.A.; Williams, K.M.; Cancel, J.D. ALS3 encodes a phloem-localized ABC transporter-like protein that is required for aluminum tolerance in Arabidopsis. Plant J. 2005, 41, 353-363. [CrossRef]

47. Wang, Y.; Li, R.; Li, D.; Jia, X.; Zhou, D.; Li, J.; Lyi, S.M.; Hou, S.; Huang, Y.; Kochian, L.V. NIP1;2 is a plasma membrane-localized transporter mediating aluminum uptake, translocation, and tolerance in Arabidopsis. Proc. Natl. Acad. Sci. USA 2017, 114, 5047-5052. [CrossRef]

48. Iuchi, S.; Koyama, H.; Iuchi, A.; Kobayashi, Y.; Kitabayashi, S.; Kobayashi, Y.; Ikka, T.; Hirayama, T.; Shinozaki, K.; Kobayashi, M. Zinc finger protein STOP1 is critical for proton tolerance in Arabidopsis and coregulates a key gene in aluminum tolerance. Proc. Natl. Acad. Sci. USA 2007, 104, 9900-9905. [CrossRef]

49. Ding, Z.J.; Yan, J.Y.; Xu, X.Y.; Li, G.X.; Zheng, S.J. WRKY46 functions as a transcriptional repressor of ALMT1, regulating aluminum-induced malate secretion in Arabidopsis. Plant J. 2013, 76, 825-835. [CrossRef]

50. Zhu, X.F.; Shi, Y.Z.; Lei, G.J.; Fry, S.C.; Zhang, B.C.; Zhou, Y.H.; Braam, J.; Jiang, T.; Xu, X.Y.; Mao, C.Z.; et al. XTH31, encoding an in vitro XEH/XET-active enzyme, regulates aluminum sensitivity by modulating in vivo XET action, cell wall xyloglucan content, and aluminum binding capacity in Arabidopsis. Plant Cell 2012, 24, 4731-4747. [CrossRef] [PubMed]

51. Daspute, A.A.; Kobayashi, Y.; Panda, S.K.; Fakrudin, B.; Kobayashi, Y.; Tokizawa, M.; Iuchi, S.; Choudhary, A.K.; Yamamoto, Y.Y.; Koyama, H. Characterization of CcSTOP1; a $\mathrm{C}_{2} \mathrm{H}_{2}$-type transcription factor regulates Al tolerance gene in pigeonpea. Planta 2018, 247, 201-214. [CrossRef] [PubMed]

52. Lei, G.J.; Yokosho, K.; Yamaji, N.; Fujii-Kashino, M.; Ma, J.F. Functional characterization of two half-size ABC transporter genes in aluminium-accumulating buckwheat. New Phytol. 2017, 215, 1080-1089. [CrossRef]

53. Wu, W.; Lin, Y.; Chen, Q.; Peng, W.; Peng, J.; Tian, J.; Liang, C.; Liao, H. Functional conservation and divergence of soybean GmSTOP1 members in proton and aluminum tolerance. Front. Plant Sci. 2018, 9, 570. [CrossRef] [PubMed]

54. Ohyama, Y.; Ito, H.; Kobayashi, Y.; Ikka, T.; Morita, A.; Kobayashi, M.; Imaizumi, R.; Aoki, T.; Komatsu, K.; Sakata, Y.; et al. Characterization of AtSTOP1 orthologous genes in tobacco and other plant species. Plant Physiol. 2013, 162, 1937-1946. [CrossRef]

55. Negishi, T.; Oshima, K.; Hattori, M.; Kanai, M.; Mano, S.; Nishimura, M.; Yoshida, K. Tonoplastand plasma membrane-localized aquaporin-family transporters in blue hydrangea sepals of aluminum hyperaccumulating plant. PLoS ONE 2012, 7, e43189. [CrossRef]

56. Zhou, G.; Delhaize, E.; Zhou, M.; Ryan, P.R. The barley MATE gene, HvAACT1, increases citrate efflux and $\mathrm{Al}^{3+}$ tolerance when expressed in wheat and barley. Ann. Bot. 2013, 112, 603-612. [CrossRef] [PubMed]

57. Huang, C.F.; Yamaji, N.; Chen, Z.; Ma, J.F. A tonoplast-localized half-size ABC transporter is required for internal detoxification of aluminum in rice. Plant J. 2012, 69, 857-867. [CrossRef]

58. Yamaji, N.; Huang, C.F.; Nagao, S.; Yano, M.; Sato, Y.; Nagamura, Y.; Ma, J.F. A zinc finger transcription factor ART1 regulates multiple genes implicated in aluminum tolerance in rice. Plant Cell 2009, 21, 3339-3349. [CrossRef] 
59. Che, J.; Tsutsui, T.; Yokosho, K.; Yamaji, N.; Ma, J.F. Functional characterization of an aluminum (Al)-inducible transcription factor, ART2, revealed a different pathway for Al tolerance in rice. New Phytol. 2018, 220, 209-218. [CrossRef]

60. Arenhart, R.A.; Schunemann, M.; Neto, L.B.; Margis, R.; Wang, Z.Y.; Margis-Pinheiro, M. Rice ASR1 and ASR5 are complementary transcription factors regulating aluminum responsive genes. Plant Cell Environ. 2016, 39, 645-651. [CrossRef]

61. Arenhart, R.A.; Margis, R.; Margis-Pinheiro, M. The rice ASR5 protein: A putative role in the response to aluminum photosynthesis disturbance. Plant Signal. Behav. 2012, 7, 1263-1266. [CrossRef] [PubMed]

62. Xia, J.X.; Yamaji, N.; Ma, J.F. A plasma membrane-localized small peptide is involved in rice aluminum tolerance. Plant J. 2013, 76, 345-355. [CrossRef]

63. Che, J.; Yamaji, N.; Shen, R.F.; Ma, J.F. An Al-inducible expansin gene, OsEXPA10 is involved in root cell elongation of rice. Plant J. 2016, 88, 132-142. [CrossRef] [PubMed]

64. Yokosho, K.; Yamaji, N.; Kashino-Fujii, M.; Ma, J.F. Retrotransposon-mediated aluminum tolerance through enhanced expression of the citrate transporter OsFRDL4. Plant Physiol. 2016, 172, 2327-2336. [CrossRef] [PubMed]

65. Chen, Z.C.; Yamaji, N.; Motoyama, R.; Nagamura, Y.; Ma, J.F. Up-regulation of a magnesium transporter gene OsMGT1 is required for conferring aluminum tolerance in rice. Plant Physiol. 2012, 159, 1624-1633. [CrossRef] [PubMed]

66. Xia, J.; Yamaji, N.; Kasai, T.; Ma, J.F. Plasma membrane-localized transporter for aluminum in rice. Proc. Natl. Acad. Sci. USA 2010, 107, 18381-18385. [CrossRef] [PubMed]

67. Huang, C.F.; Yamaji, N.; Mitani, N.; Yano, M.; Nagamura, Y.; Ma, J.F. A bacterial-type ABC transporter is involved in aluminum tolerance in rice. Plant Cell 2009, 21, 655-667. [CrossRef] [PubMed]

68. Li, G.Z.; Wang, Z.Q.; Yokosho, K.; Ding, B.; Fan, W.; Gong, Q.Q.; Li, G.X.; Wu, Y.R.; Yang, J.L.; Ma, J.F.; et al. Transcription factor WRKY22 promotes aluminum tolerance via activation of OsFRDL4 expression and enhancement of citrate secretion in rice (Oryza sativa). New Phytol. 2018, 219, 149-162. [CrossRef]

69. Huang, S.; Gao, J.; You, J. Identification of STOP1-Like proteins associated with aluminum tolerance in sweet sorghum (Sorghum bicolor L.). Front. Plant Sci. 2018, 9, 258. [CrossRef]

70. Melo, J.O.; Martins, L.G.; Barros, B.A.; Pimenta, M.R.; Lana, U.G.; Duarte, C.E.; Pastina, M.M.; Guimaraes, C.T.; Schaffert, R.E.; Kochian, L.V.; et al. Repeat variants for the SbMATE transporter protect sorghum roots from aluminum toxicity by transcriptional interplay in cis and trans. Proc. Natl. Acad. Sci. USA 2019, 116, 313-318. [CrossRef]

71. Tovkach, A.; Ryan, P.R.; Richardson, A.E.; Lewis, D.C.; Rathjen, T.M.; Ramesh, S.; Tyerman, S.D.; Delhaize, E. Transposon-mediated alteration of TaMATE1B expression in wheat confers constitutive citrate efflux from root apices. Plant Physiol. 2013, 161, 880-892. [CrossRef]

72. Garcia-Oliveira, A.L.; Benito, C.; Prieto, P.; Menezes, R.D.A.; Rodrigues-Pousada, C.; Guedes-Pinto, H.; Martins-Lopes, P. Molecular characterization of TaSTOP1 homoeologues and their response to aluminium and proton $\left(\mathrm{H}^{+}\right)$toxicity in bread wheat (Triticum aestivum L.). BMC Plant Biol. 2013, 13, 134. [CrossRef]

73. Fan, W.; Lou, H.Q.; Gong, Y.L.; Liu, M.Y.; Cao, M.J.; Liu, Y.; Yang, J.L.; Zheng, S.J. Characterization of an inducible $\mathrm{C}_{2} \mathrm{H}_{2}$-type zinc finger transcription factor VuSTOP1 in rice bean (Vigna umbellata) reveals differential regulation between low $\mathrm{pH}$ and aluminum tolerance mechanisms. New Phytol. 2015, 208, 456-468. [CrossRef]

74. Ma, J.F.; Ryan, P.R.; Delhaize, E. Aluminium tolerance in plants and the complexing role of organic acids. Trends Plant Sci. 2001, 6, 273-278. [CrossRef]

75. Ma, J.F. Role of organic acids in detoxification of aluminum in higher plants. Plant Cell Physiol. 2000, 41, 383-390. [CrossRef] [PubMed]

76. Delhaize, E.; Ryan, P.R.; Randall, P.J. Aluminum tolerance in wheat (Triticum aestivum L.) II. Aluminum-stimulated excretion of malic acid from root apices. Plant Physiol. 1993, 103, 695-702. [CrossRef] [PubMed]

77. Zheng, S.J.; Ma, J.F.; Matsumoto, H. High aluminum resistance in buckwheat. I. Al-induced specific secretion of oxalic acid from root tips. Plant Physiol. 1998, 117, 745-751. [CrossRef]

78. Delhaize, E.; Ryan, P.R. Aluminum toxicity and tolerance in plants. Plant Physiol. 1995, 107, $315-321$. [CrossRef] [PubMed] 
79. Pineros, M.A.; Cancxado, G.A.A.; Kochian, L.V. Novel properties of the wheat aluminum tolerance organic acid transporter (TaALMT1) revealed by electrophysiological characterization in Xenopus Oocytes: Functional and structural implications. Plant Physiol. 2008, 147, 2131-2146. [CrossRef]

80. Furuichi, T.; Sasaki, T.; Tsuchiya, Y.; Ryan, P.R.; Delhaize, E.; Yamamoto, Y. An extracellular hydrophilic carboxy-terminal domain regulates the activity of TaALMT1, the aluminum-activated malate transport protein of wheat. Plant J. 2010, 64, 47-55. [CrossRef]

81. Ligaba, A.; Dreyer, I.; Margaryan, A.; Schneider, D.J.; Kochian, L.; Piñeros, M. Functional, structural and phylogenetic analysis of domains underlying the $\mathrm{Al}$ sensitivity of the aluminum-activated malate/anion transporter, TaALMT1. Plant J. 2013, 76, 766-780. [CrossRef]

82. Ramesh, S.A.; Tyerman, S.D.; Xu, B.; Bose, J.; Kaur, S.; Conn, V. GABA signalling modulates plant growth by directly regulating the activity of plant-specific anion transporters. Nat. Commun. 2015, 6, 7879. [CrossRef] [PubMed]

83. Ramesh, S.A.; Kamran, M.; Sullivan, W.; Chirkova, L.; Okamoto, M.; Degryse, F.; McLaughlin, M.; Gilliham, M.; Tyerman, S.D. Aluminum-activated malate transporters can facilitate GABA transport. Plant Cell 2018, 30, 1147-1164. [CrossRef] [PubMed]

84. Kidd, P.S.; Llugany, M.; Poschenrieder, C.; Gunsé, B.; Barceló, J. The role of root exudates in aluminium resistance and silicon-induced amelioration of aluminium toxicity in three varieties of maize (Zea mays L.). J. Exp. Bot. 2001, 52, 1339-1352. [PubMed]

85. Zhao, Z.; Gao, X.; Ke, Y.; Chang, M.; Xie, L.; Li, X.; Gu, M.; Liu, J.; Tang, X. A unique aluminum resistance mechanism conferred by aluminum and salicylic-acid-activated root efflux of benzoxazinoids in maize. Plant Soil 2019, 1-17. [CrossRef]

86. Yang, Y.; Wang, Q.L.; Geng, M.J.; Guo, Z.H.; Zhao, Z. Rhizosphere pH difference regulated by plasma membrane $\mathrm{H}^{+}$-ATPase is related to differential Al tolerance of two wheat cultivars. Plant Soil Environ. 2011, 57, 201-206. [CrossRef]

87. Jörg, D.; Paul, B.L.; Stephen, H.H.; Leon, V.K. Aluminum resistance in the Arabidopsis mutant alr-104 is caused by an aluminum-induced increase in rhizosphere pH. Plant Physiol. 1998, 117, 19-27.

88. Kochian, L.V.; Hoekenga, O.A.; Pineros, M.A. How do crop plants tolerate acid soils? Mechanisms of aluminum tolerance and phosphorous efficiency. Annu. Rev. Plant Biol. 2004, 55, 459-493. [CrossRef]

89. Yang, J.L.; Li, Y.Y.; Zhang, Y.J.; Zhang, S.S.; Wu, Y.R.; Wu, P.; Zheng, S.J. Cell wall polysaccharides are specifically involved in the exclusion of aluminum from the rice root apex. Plant Physiol. 2008, 146, 602-611. [CrossRef]

90. Rangel, A.F.; Rao, I.M.; Horst, W.J. Intracellular distribution and binding state of aluminum in root apices of two common bean (Phaseolus vulgaris) genotypes in relation to Al toxicity. Physiol. Plant 2009, 135, 162-173. [CrossRef]

91. Sasidharan, R.; Voesenek, L.A.; Pierik, R. Cell wall modifying proteins mediate plant acclimatization to biotic and abiotic stresses. Crit. Rev. Plant Sci. 2011, 30, 548-562. [CrossRef]

92. Yang, J.L.; Zhu, X.F.; Peng, Y.X.; Zheng, C.; Li, G.X.; Liu, Y.; Shi, Y.Z.; Zheng, S.J. Cell wall hemicellulose contributes significantly to aluminum adsorption and root growth in Arabidopsis. Plant Physiol. 2011, 155, 1885-1892. [CrossRef]

93. Tabuchi, A.; Matsumoto, H. Changes in cell-wall properties of wheat (Triticum aestivum) roots during aluminum-induced growth inhibition. Physiol. Plant. 2001, 112, 353-358. [CrossRef] [PubMed]

94. Eticha, D.; Stass, A.; Horst, W.J. Cell-wall pectin and its degree of methylation in the maize root-apex: Significance for genotypic differences in aluminium resistance. Plant Cell Environ. 2005, 28, 1410-1420. [CrossRef]

95. Yang, X.Y.; Zeng, Z.H.; Yan, J.Y.; Fan, W.; Bian, H.W.; Zhu, M.Y.; Yang, J.L.; Zheng, S.J. Association of specific pectin methylesterases with Al-induced root elongation inhibition in rice. Physiol. Plant 2013, 148, 502-511. [CrossRef]

96. Jan, A.; Yang, G.; Nakamura, H.; Ichikawa, H.; Kitano, H.; Matsuoka, M.; Matsumoto, H.; Komatsu, S. Characterization of a xyloglucan endotransglucosylase gene that is up-regulated by gibberellin in rice. Plant Physiol. 2004, 136, 3670-3681. [CrossRef] [PubMed] 
97. Pitaksaringkarn, W.; Matsuoka, K.; Asahina, M.; Miura, K.; Sage-Ono, K.; Ono, M.; Yokoyama, R.; Nishitani, K.; Ishii, T.; Iwai, H.; et al. XTH 20 and XTH 19 regulated by ANAC 071 under auxin flow are involved in cell proliferation in incised Arabidopsis inflorescence stems. Plant J. 2014, 80, 604-614. [CrossRef]

98. Lu, M.; Yang, G.; Li, P.; Wang, Z.; Fu, S.; Zhang, X.; Chen, X.; Shi, M.; Ming, Z.; Xia, J. Bioinformatic and functional analysis of a key determinant underlying the substrate selectivity of the Al transporter, Nrat1. Front. Plant Sci. 2018, 9, 606. [CrossRef]

99. Shen, R.; Iwashita, T.; Ma, J.F. Form of $\mathrm{Al}$ changes with $\mathrm{Al}$ concentration in leaves of buckwheat. J. Exp. Bot. 2004, 55, 131-136. [CrossRef]

100. Ma, J.F.; Hiradate, S.; Nomoto, K.; Iwashita, T.; Matsumoto, H. Internal detoxification mechanism of $\mathrm{Al}$ in hydrangea (identification of Al form in the leaves). Plant Physiol. 1997, 113, 1033-1039. [CrossRef]

101. Carr, H.P.; Lombi, E.; Küpper, H.; McGrath, S.P.; Wong, M.H. Accumulation and distribution of aluminium and other elements in tea (Camellia sinensis) leaves. Agronomie 2003, 23, 705-710. [CrossRef]

102. Watanabe, T.; Osaki, M.; Yoshihara, T.; Tadano, T. Distribution and chemical speciation of aluminum in the Al accumulator plant, Melastoma malabathricum L. Plant Soil 1998, 201, 165-173. [CrossRef]

103. Nagata, T.; Hayatsu, M.; Kosuge, N. Identification of aluminium forms in tea leaves by ${ }^{27} \mathrm{Al}$ NMR. Phytochemistry 1992, 31, 1215-1218. [CrossRef]

104. Singh, K.B.; Foley, R.C.; Oñate-Sánchez, L. Transcription factors in plant defense and stress responses. Curr. Opin. Plant Biol. 2002, 5, 430-436. [CrossRef]

105. Sawaki, Y.; Iuchi, S.; Kobayashi, Y.; Kobayashi, Y.; Ikka, T.; Sakurai, N.; Fujita, M.; Shinozaki, K.; Shibata, D.; Kobayashi, M.; et al. STOP1 regulates multiple genes that protect Arabidopsis from proton and aluminum toxicities. Plant Physiol. 2009, 150, 281-294. [CrossRef] [PubMed]

106. Kobayashi, Y.; Hoekenga, O.A.; Itoh, H.; Nakashima, M.; Saito, S.; Shaff, J.E.; Maron, L.G.; Piñeros, M.A.; Kochian, L.V.; Koyama, H. Characterization of AtALMT1 expression in aluminum-inducible malate release and its role for rhizotoxic stress tolerance in Arabidopsis. Plant Physiol. 2007, 145, 843-852. [CrossRef]

107. Zhang, Y.; Zhang, J.; Guo, J.; Zhou, F.; Singh, S.; Xu, X.; Xie, Q.; Yang, Z.; Huang, C.F. F-box protein RAE1 regulates the stability of the aluminum-resistance transcription factor STOP1 in Arabidopsis. Proc. Natl. Acad. Sci. USA 2018, 116, 319-327. [CrossRef]

108. Arenhart, R.A.; Bai, Y.; de Oliveira, L.F.V.; Neto, L.B.; Schunemann, M.; Maraschin, F.S.; Mariath, J.; Silverio, A.; Sachetto-Martins, G.; Margis, R. New insights into aluminum tolerance in rice: The ASR5 protein binds the STAR1 promoter and other aluminum-responsive genes. Mol. Plant 2014, 7, 709-721. [CrossRef] [PubMed]

109. Arenhart, R.A.; Lima, J.C.D.; Pedron, M.; Carvalho, F.E.L.; Silveira, J.A.G.D.; Rosa, S.B.; Caverzan, A.; Andrade, C.M.B.; Schünemann, M.; Margis, R.; et al. Involvement of ASR genes in aluminium tolerance mechanisms in rice. Plant Cell Environ. 2013, 36, 52-67. [CrossRef]

110. Ryan, P.R.; Raman, H.; Gupta, S.; Sasaki, T.; Yamamoto, Y.; Delhaize, E. The multiple origins of aluminium resistance in hexaploid wheat include Aegilops tauschii and more recent cis mutations to TaALMT1. Plant J. 2010, 64, 446-455. [CrossRef]

111. Fujii, M.; Yokosho, K.; Yamaji, N.; Saisho, D.; Yamane, M.; Takahashi, H.; Sato, K.; Nakazono, M.; Ma, J.F. Acquisition of aluminium tolerance by modification of a single gene in barley. Nat. Commun. 2012, 3, 713. [CrossRef]

112. Maron, L.G.; Guimarães, C.T.; Kirst, M.; Albert, P.S.; Birchler, J.A.; Bradbury, P.J.; Buckler, E.S.; Coluccio, A.E.; Danilova, T.V.; Kudrna, D.; et al. Aluminum tolerance in maize is associated with higher MATE1 gene copy number. Proc. Natl. Acad. Sci. USA 2013, 110, 5241-5246. [CrossRef]

113. Lima, J.C.; Arenhart, R.A.; Margis-Pinheiro, M.; Margis, R. Aluminum triggers broad changes in microRNA expression in rice roots. Genet. Mol. Res. 2011, 10, 2817-2832. [CrossRef]

114. Zeng, Q.Y.; Yang, C.Y.; Ma, Q.B.; Li, X.P.; Dong, W.W.; Nian, H. Identification of wild soybean miRNAs and their target genes responsive to aluminum stress. BMC Plant Biol. 2012, 12, 182. [CrossRef] [PubMed]

115. Wu, L.; Yu, J.; Shen, Q.; Huang, L.; Wu, D.; Zhang, G. Identification of microRNAs in response to aluminum stress in the roots of Tibetan wild barley and cultivated barley. BMC Genom. 2018, 19, 560. [CrossRef]

116. Seguel, A.; Cumming, J.R.; Klugh-Stewart, K.; Cornejo, P.; Borie, F. The role of arbuscular mycorrhizas in decreasing aluminium phytotoxicity in acidic soils: A review. Mycorrhiza 2013, 23, 167-183. [CrossRef] [PubMed] 
117. Rufyikiri, G.; Nootens, D.; Dufey, J.E.; Delvaux, B. Effect of aluminium on bananas (Musa spp.) cultivated in acid solutions. I. Plant growth and chemical composition. Fruits 2000, 55, 367-379.

118. Arriagada, C.A.; Herrera, M.A.; Borie, F.; Ocampo, J.A. Contribution of arbuscular mycorrhizal and saprobe fungi to the aluminum resistance of Eucalyptus globulus. Water Air Soil Pollut. 2007, 182, 383-394. [CrossRef]

119. Seguel, A.; Castillo, C.G.; Morales, A.; Campos, P.; Cornejo, P.; Borie, F. Arbuscular mycorrhizal symbiosis in four Al-tolerant wheat genotypes grown in an acidic andisol. J. Plant Nutr. Soil Sci. 2016, 16, 164-173. [CrossRef]

120. Lux, H.B.; Cumming, J.R. Mycorrhizae confer aluminum resistance to tulip-poplar seedlings. Can. J. For. Res. 2001, 31, 694-702. [CrossRef]

121. Klugh, K.R.; Cumming, J.R. Variations in organic acid exudation and aluminum resistance among arbuscular mycorrhizal species colonizing Liriodendron tulipifera. Tree Physiol. 2007, 27, 1103-1112. [CrossRef]

122. Etcheverría, P. Glomalin in evergreen forest associations, deciduous forest and a plantation of Pseudotsuga menziesii in the X Región, Chile. Ph.D. Thesis, Universidad de La Frontera, Temuco, Chile, 2009.

123. Joner, E.J.; Briones, R.; Leyval, C. Metal-binding capacity of arbuscular mycorrhizal mycelium. Plant Soil. 2000, 226, 227-234. [CrossRef]

124. Göhre, V.; Paszkowski, U. Contribution of the arbuscular mycorrhizal symbiosis to heavy metal phytoremediation. Planta 2006, 223, 1115-1122. [CrossRef] [PubMed]

125. Li, X.L.; George, E.; Marschner, H. Extension of the phosphorus depletion zone in VA-mycorrhizal white clover in a calcareous soil. Plant Soil 1991, 136, 41-48. [CrossRef]

126. Tarafdar, J.C.; Marschner, H. Phosphatase activity in the rhizosphere and hyphosphere of VA mycorrhizal wheat supplied with inorganic and organic phosphorus. Soil Biol. Biochem. 1994, 26, 387-395. [CrossRef]

127. Delhaize, E.; Ryan, P.R.; Hebb, D.M.; Yamamoto, Y.; Sasaki, T.; Matsumoto, H. Engineering high-level aluminum tolerance in barley with the ALMT1 gene. Proc. Natl. Acad. Sci. USA 2004, 101, 15249-15254. [CrossRef]

128. Pereira, J.F.; Zhou, G.; Delhaize, E.; Richardson, T.; Zhou, M.; Ryan, P.R. Engineering greater aluminium resistance in wheat by over-expressing TaALMT1. Ann. Bot. 2010, 106, 205-214. [CrossRef] [PubMed]

(C) 2019 by the authors. Licensee MDPI, Basel, Switzerland. This article is an open access article distributed under the terms and conditions of the Creative Commons Attribution (CC BY) license (http:/ / creativecommons.org/licenses/by/4.0/). 